\title{
Costa Rica's Payment for Environmental Services Program: Intention, Implementation, and Impact
}

\author{
G. ARTURO SÁNCHEZ-AZOFEIFA, ${ }^{*}$ ALEXANDER PFAFF, $†$ JUAN ANDRES ROBALINO, $†$ \\ AND JUDSON P. BOOMHOWER $\ddagger$
}

*Earth Observation Systems Laboratory, Department of Earth and Atmospheric Sciences, University of Alberta, Edmonton, Alberta T6G 2E3, Canada, email arturo.sanchez@ualberta.ca

†The Earth Institute, 2910 Broadway, Hogan Hall 104, Columbia University, New York, NY 10025, U.S.A.

$\ddagger$ Center for Conservation Biology, Department of Biological Sciences, 371 Serra Mall, Stanford University, Stanford, CA 94305-5020, U.S.A.

\begin{abstract}
We evaluated the intention, implementation, and impact of Costa Rica's program of payments for environmental services (PSA), which was established in the late 1990s. Payments are given to private landowners who own land in forest areas in recognition of the ecosystem services their land provides. To characterize the distribution of PSA in Costa Rica, we combined remote sensing with geographic information system databases and then used econometrics to explore the impacts of payments on deforestation. Payments were distributed broadly across ecological and socioeconomic gradients, but the 1997-2000 deforestation rate was not significantly lower in areas that received payments. Other successful Costa Rican conservation policies, including those prior to the PSA program, may explain the current reduction in deforestation rates. The PSA program is a major advance in the global institutionalization of ecosystem investments because few, if any, other countries have such a conservation history and because much can be learned from Costa Rica's experiences.
\end{abstract}

Keywords: Costa Rica, deforestation trends, ecosystems services, payment for environmental services, PSA

El Programa de Pago de Servicios Ambientales de Costa Rica: Intención, Implementación e Impacto

Resumen: Evaluamos la intención, implementación e impacto del programa de pago de servicios ambientales (PSA) de Costa Rica, que fue establecido al final de la década de 1990. Los pagos son otorgados a propietarios privados en áreas boscosas como reconocimiento a los servicios ecosistémicos que proporcionan sus tierras. Para caracterizar la distribución de PSA en Costa Rica, combinamos bases de datos de percepción remota y de sistemas de información geográfica y posteriormente utilizamos econometría para explorar los impactos de los pagos sobre la deforestación. Los pagos fueron ampliamente distribuidos a lo largo de gradientes ecológicos y socioeconómicos, pero la tasa de deforestación 1997-2000 no fue significativamente menor en las áreas que recibieron pagos. Otras políticas costarricenses de conservación exitosas, incluyendo algunas previas al programa PSA, pueden explicar la reducción actual de tasas de deforestación. El programa PSA es un avance importante en la institucionalización global de las inversiones en ecosistemas porque pocos, si alguno, países tienen tal bistoria de conservación y porque se puede aprender mucho de las experiencias de Costa Rica.

Palabras Clave: Costa Rica, pago de servicios ambientales, PSA, servicios ecosistémicos, tendencias de deforestación

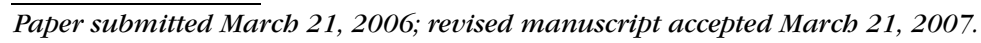




\section{Introduction}

A new generation of conservation approaches is rapidly emerging (Ferraro \& Kiss 2002; Pagiola et al. 2002). They differ from traditional approaches in three critical and interrelated ways: they emphasize human-dominated landscapes, focus on ecosystem services, and utilize innovative finance mechanisms. To date, however, their implementation has been on a small spatial scale. To apply the most promising initiatives worldwide, it is critical to understand their intentions, designs, scopes, and limitations (Ferraro 2001). Ecosystems provide services that include the pollination of crops, renewal of soil fertility, purification of water, and stabilization of climate. For global services, such as the sequestration of carbon to aid in climate stability, the origin of the service does not matter. Nevertheless, many services are supplied across local and regional scales; thus, their delivery hinges on the capacity of species and ecosystems to provide benefits precisely where humans are located. Therefore, success in conservation and many other aspects of human wellbeing is linked intimately to the management of highly fragmented landscapes (Janzen 1998; McNeely \& Scherr 2002).

Incentives for maintaining the provision of ecosystem services (Pagiola et al. 2002; Pagiola et al. 2004; Newburn et al. 2005) include many components. Among them are regulatory systems of payments for ecosystem services, such as those currently operating in countries such as Australia, Costa Rica, and Mexico; market-based approaches to paying for ecosystem services, such as the emerging international carbon market; and mitigation banking approaches, such as those operating in the United States in the context of the Clean Water Act and the Endangered Species Act. Conservation programs under the European Common Agricultural Policy and the U.S. Farm Bill, in addition to various financial-incentive schemes of The World Bank, are also important initiatives.

We explored the inception and initial impact of the first generation (1997-2000) of an innovative conservation program established in Costa Rica: payments for environmental services, or PSA (pagos por servicios ambientales). The PSA program in Costa Rica occurred in two phases. The first phase (1997-2000) coincided with a significant drop in the national rate of deforestation (1997-2000), relative to the 1986-1997 time period and the high rates of forest clearing that occurred from the 1960s to the early 1980s (Sánchez-Azofeifa et al. 2001). Recently, there has been a net increase in forest cover, mostly due to land abandonment, although this process is not sufficient to reverse the existing fragmentation of the landscape or the increasing isolation of the country's national parks and biological reserves (Sánchez-Azofeifa et al. 2003). The second phase of the PSA program relates to the implementation of the Ecomarkets project (2001-today) and involves a comprehensive microtargeting scheme and the provision of new ecosystem services (e.g., drinking water) that were not part of the first phase.

It is tempting to assign credit for the decrease in deforestation rates to the implementation of the PSA program. However, assigning causality to a farm-level program of this type requires a detailed analysis of deforestation over space and time and controls for other drivers of change (e.g., international price of meat). Only by controlling for the effects of other factors (e.g., strong forestry legislation), can one conclude that the implementation of the PSA program and low rates of forest clearing are not merely coincidental. Furthermore, how the PSA payments were allocated needs to be taken into account.

We examined the effect of the first phase (1997-2000) of Costa Rica's PSA program on ecological life zones, hydrological basins, buffer zones around protected areas, planned biological corridors, and deforestation fronts. To test the hypothesis that the first generation of the PSA program has had an impact on the current low deforestation rates, we examined payment allocation relative to the future threat of clearing and land-use changes in deforestation over space and time.

\section{Intent of Costa Rica's PSA Program}

Three laws form the framework within which Costa Rica established the PSA program. The 1995 Environment Law 7554 mandates a "balanced and ecologically driven environment" for all. The 1996 Forestry Law 7575 mandates "rational use" of all natural resources and prohibits landcover change in forests. Finally, the 1998 Biodiversity Law promotes the conservation and "rational use" of biodiversity resources.

Payments in the first phase were designed to address relevant forest conservation failures from a legal and institutional standpoint. The PSA program compensated forest landowners for value created by either planted or natural forest on their land and recognized four services: (1) greenhouse gas mitigation; (2) hydrological services; (3) scenic value; and (4) biodiversity. The program did not attempt to measure all four services on a given parcel at once. An identically valued bundle of these services was assumed to be provided by each hectare of enrolled parcel. In the first phase enrollment was not based on parcel size, and the policy was "first come, first served." Factors such as farm size, human capital, and household economic level influenced participation in the program, and large landowners were disproportionately represented among participants at the national and regional levels (Miranda et al. 2003; Zbinden \& Lee 2005).

The PSA program has to compete with other land-use returns. Average returns from PSA varied from US\$22 to 
US $\$ 42 / \mathrm{ha} /$ year before fencing, tree planting, and certification costs. The main competing land use is cattle ranching, which shows returns from US\$8 to US\$125, depending on location, land type, and ranching practices (ArroyoMora et al. 2005). One measure of cattle-ranching returns is the cost of renting 1 ha of pasture. In Cordillera Central, in the heart of Costa Rica, pasture rental ranges from US\$20 to US\$30/ha/year (Castro et al. 1998).

\section{Implementation of the PSA}

Three types of contracts were part of the first phase of the PSA program: forest conservation, reforestation, and sustainable forest management. Forest conservation contracts required land owners to protect existing (primary or secondary) forest for 5 years, with no land-cover change allowed. Reforestation contracts bound owners to plant trees on agricultural or other abandoned land and to maintain that plantation for 15 years. Sustainable forest management contracts (eliminated briefly in 2000) compensated landowners who prepared a "sustainable logging plan" to conduct low-intensity logging while keeping forest services intact. Just as in the reforestation contracts, obligations for sustainable forest management contracts were for 15 years, although payments arrived during the first 5 years.

Compensation varied across these types of contracts. For conservation contracts, payment was US $\$ 210(60,000$ colones)/ha in equal installments over 5 years. Reforestation contracts paid US\$537 (154,000 colones)/ha, with $50 \%$ paid the first year, $20 \%$ the second year, and $10 \%$ over the following 3 years. The forest management contracts paid US\$327 (94,000 colones)/ha, with the same temporal structure as reforestation. Our conversion to U.S. dollars was based on the 1999 average exchange (287 colones/U.S. dollar) rate provided by the Costa Rican Ministry of Planning (MIDEPLAN). (Hereafter monetary units are in U.S. dollars unless otherwise indicated.)

Any PSA contract creates a legal easement that remains with the property if it is sold. Owners transfer rights to the greenhouse-gas-mitigation potential of the parcel to the national government. Costa Rica can then sell these abatement units on any international market. Under the PSA program rules, no individual can register $<2$ ha or $>300$ ha/year, although indigenous groups may register up to $600 \mathrm{ha} /$ year. There is no area limit for coalitions that act through local nongovernmental organizations. Such organizations can function as intermediaries between smallholders and authorities to increase participation by those who might not enroll.

The Fondo Nacional de Financiamiento Forestal (FONAFIFO), a public forestry-financing agency created under Forestry Law 7575 in 1996, administers the PSA program. The inspection responsibilities within the program's im- plementation, however, rest with the Sistema Nacional de Areas de Conservacion (SINAC) and with the Ministerio del Ambiente y Energía (MINAE).

The primary funding source for the original PSA program was a $15 \%$ consumer tax on fossil fuels established under the 1996 Forestry Law. Its Article 69 stated that FONAFIFO was to receive one-third of the revenue. The Ministry of Finance, however, rarely delivered that amount, and in 2001 the legislature repealed Article 69 and adopted the Ley de Simplificación y Eficiencia Tributaria, which assigns $3.5 \%$ of the tax revenue directly to the PSA program (Camacho \& Reyes 2002). This provided less money in theory, but increased actual transfers from the Ministry of Finance (Camacho \& Reyes 2002). As of 2003 , such tax revenues provided an average of $\$ 6.4$ million/year to the PSA program (Pagiola et al. 2002).

Funding to the PSA program also comes from voluntary contracts with private hydroelectric producers, who reimburse FONAFIFO for payments given to individuals such as upstream landowners in watersheds. These private agreements have generated only about $\$ 100,000$ to finance about 2,400 ha of PSA contracts. When fully implemented, however, these agreements are expected to provide about $\$ 600,000$ annually and to cover close to 18,000 ha (Pagiola et al. 2002).

Carbon-abatement trading was expected to provide significant funding through sales of certified tradable offsets. However, no significant market for carbon abatement has emerged. The only sale has been to Norway, which consisted of \$2 million in 1997 for 200 million tons of carbon sequestration (Pagiola et al. 2002).

Funding was also provided by a World Bank loan and a Global Environmental Facility (GEF) grant through a program called Ecomercados (a term used to define the second phase of the PSA program after the year 2000). The World Bank/GEF loan for $\$ 32.6$ million was designed to support current PSA contracts. Of the total $\$ 8$ million, $\$ 5$ million was used for conservation contracts along the proposed sites that will eventually form part of the Mesoamerican Biological Corridor. The other $\$ 3$ million was intended to increase human, administrative, and monitoring capacity in the various institutions associated with the program, including FONAFIFO, SINAC, and MINAE (Ortiz \& Kellenberg 2002).

\section{Methods}

\section{Data on Payments, Forest Cover, and Dimensions of Conservation Interest}

The data on the payment amounts for environmental services to landowners were provided by FONAFIFO. The information on contracts we analyzed is available in vector format, including the spatial location of the farms that participate in the different types of PSA contracts. We 
quantified forest cover and change based on a comprehensive Landsat Thematic Mapper data set produced for FONAFIFO by the University of Alberta's Earth Observation Systems Laboratory (EOSL) and the School of Forestry at the Costa Rica Technology Institute. The forest-cover maps were produced for 1986, 1997, and 2000. The following five land-cover categories were mapped: (1) forest (canopy closure $>80 \%$ ), (2) 1986-1997 and 1997-2000 deforestation and reforestation, (3) mangroves, (4) nonforest, and (5) cloud/water cover. The maps had a minimum mapping unit of 3.0 ha and were generated with the same techniques implemented by the NASA Pathfinder Project (Skole \& Tucker 1993; Sánchez-Azofeifa et al. 2001). Over 800 independent control sites were used for the validation of the 1997 and 2000 maps (SánchezAzofeifa et al. 2001, 2003). Overall accuracy of the forestcover map was $90 \%$ (Sánchez-Azofeifa et al. 2003).

We generated a digital elevation model (DEM) from 166 digitized topographic maps (1:50,000). Elevations every $20 \mathrm{~m}$ and supplementary elevations every $10 \mathrm{~m}$ were used to create a grid DEM, with a spatial scale of $28.5 \mathrm{~m}$. We used the DEM to produce drainage-basin boundaries and slope and aspect maps.

A series of thematic GIS maps delineating different hydrological, biological, and conservation land uses were cross-referenced against the extent of national parks and biological reserves. Those GIS maps were of (1) drainage basins important for hydropower production, drinkingwater supply, and flood control (Sánchez-Azofeifa et al. 2002a); (2) areas with potential for biological corridors that may become part of the Mesoamerican Biological Corridor efforts (known as GRUAS); (3) Holdridge life zones (Holdridge 1967); and (4) political boundaries of the 13 conservation areas in Costa Rica. National park and biological reserve areas falling in each one of the former GIS maps were eliminated because PSA payments are not allowed for public lands.

From the point of view of water resource management, we placed all drainage basins into one of four categories: (1) basins in which the management of water quality is considered especially important (4 drainage basins), (2) basins not important for water quality, (3) basins with existing or planned dams for hydropower (8 drainage basins), and basins not planned for hydropower dams (Sánchez-Azofeifa et al. 2002a). Finally, we explored the spatial distribution of PSA in 1- and 5-km buffer areas around national parks, biological reserves, and 19972000 deforestation fronts (Sánchez-Azofeifa et al. 2003; Van Laake \& Sánchez-Azofeifa 2004).

\section{Data Analysis}

To reveal the spatial distribution of PSA contracts, we overlaid them with the GIS layers described above. For these and other analyses, when a PSA polygon crossed a border between two defined categories (e.g., two differ- ent life zones), its area was divided across those units as a function of the total area falling within each category. To explore the effects of PSA contracts on changes in forest cover due to clearing, we used $5 \times 5 \mathrm{~km}$ grid cells, with each cell representing a nested approach with a full resolution of $28.5 \mathrm{~m}$ and no resampling of the data.

We used forest and nonforest data (1986, 1997, and 2000) from 2000 grid cells (total country area of 50,100 $\mathrm{km}^{2}$ ) to calculate the 1986-1997 and 1997-2000 deforestation rates. Using a GIS approach, we also overlaid PSA locations in the context of (1) proximity to national parks and biological reserves, (2) slope, (3) aspect, (3) distances to three major market locations (San Jose [capital city], Limon [Caribbean coast], and Puntarenas [Pacific coast], and (4) life zones.

Life zones were classified into three categories as a function of their potential agricultural productivity: (1) "good" life zones, which included all humid areas (medium precipitation) with moderate temperature, (2) "medium" life zone, which included very humid areas (high precipitation) in moderate to mountain elevations with moderate temperatures; and (3) "poor" life zones, which included all very humid areas with high temperatures, very dry, hot areas, and rainy life zones (Pfaff \& Sánchez-Azofeifa 2004). We performed ordinary least square (OSL) regressions to explain the differences in deforestation rates across space and time based on PSA density (number of parcels per hectare) and life zones, slopes, aspect, and distances to major market locations.

Finally, we explored the hypothesis that implementation of the PSA program was based, in part, on expectations that payments for ecological services were made in areas under greatest threat of forest conversion as suggested by Pfaff and Sánchez-Azofeifa (2004). We examined this hypothesis by studying the proximity of the payments to recent deforestation as an indicator of expected threat (i.e., payments within $1 \mathrm{~km}$ of recent 1986-2000 deforestation).

\section{Results}

\section{Total Distribution of PSA Contracts}

Around 300,000 ha of primary, secondary, or planted forest received funding in the first phase of the PSA program through 2000. The mean project size was approximately $102 \mathrm{ha}$. The largest project was $4025 \mathrm{ha}$. The stated size limits were not fully enforced; 202 projects were over the 300-ha maximum and 60 contained less than the 2-ha minimum. From 1997 to 2000, the number of participants entering the program decreased (Fig. 1), probably because funds were not delivered as expected (Camacho \& Reyes 2002).

Payments for conservation alone were larger than the sum of the payments made for reforestation and forest 


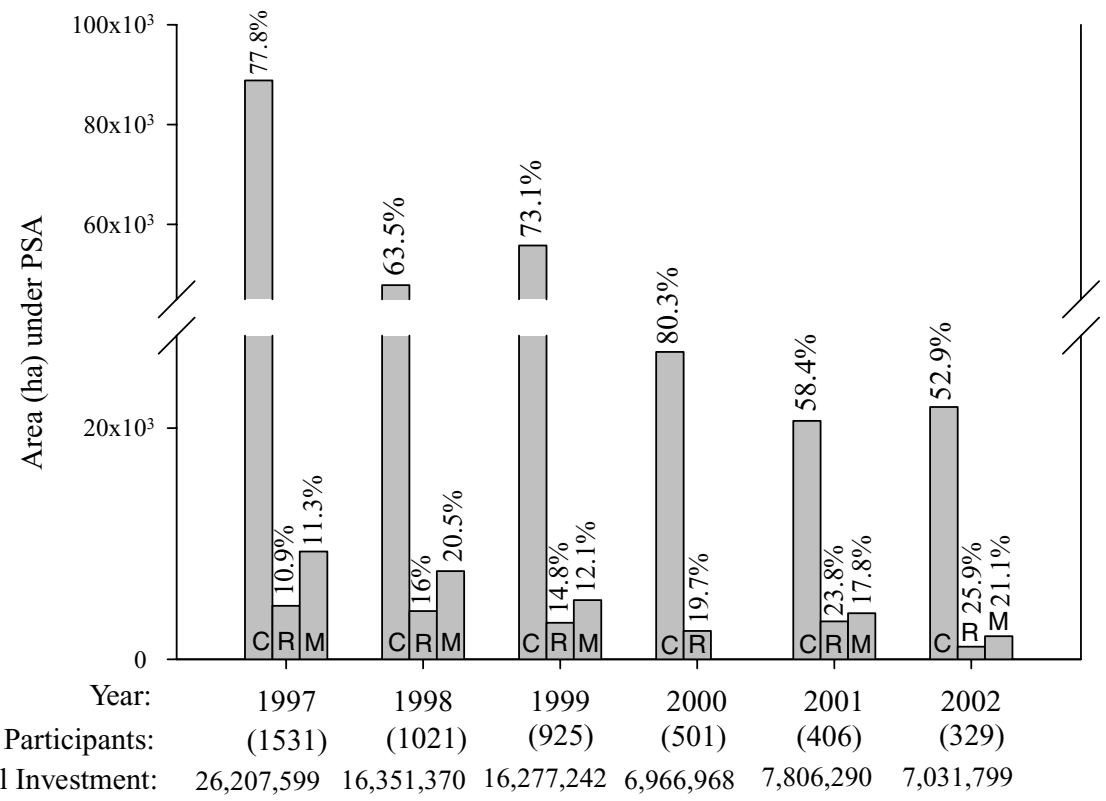

Figure 1. Distribution of PSA (payments for ecosystem services) in Costa Rica by type of payment ( $C$, conservation; $R$, reforestation; and $M$, management) between 1997 and 2002. The number of people involved in the program and the total investment (in U.S. dollars) are presented for each year. management (Fig. 1), but conservation contracts had the lowest payments per unit area. Reforestation and management contracts generally held steady over the years, whereas conservation payments fell (e.g., $>\$ 20$ million in 1997; almost $\$ 12$ million in 1999; and $<\$ 4$ million in 2001).

\section{Spatial Allocation of PSA Contracts}

The PSA contracts were distributed broadly across ecological life zones (Table 1). Most life zones had areas under PSA ranging from $4 \%$ to $8 \%$ of their total area. The maximum allocation was achieved for Very Humid Tropical

Table 1. Distributions of PAS (payment for ecosystem services) on Costa Rican lands outside of protected areas between 1997 and $2000 .^{a}$

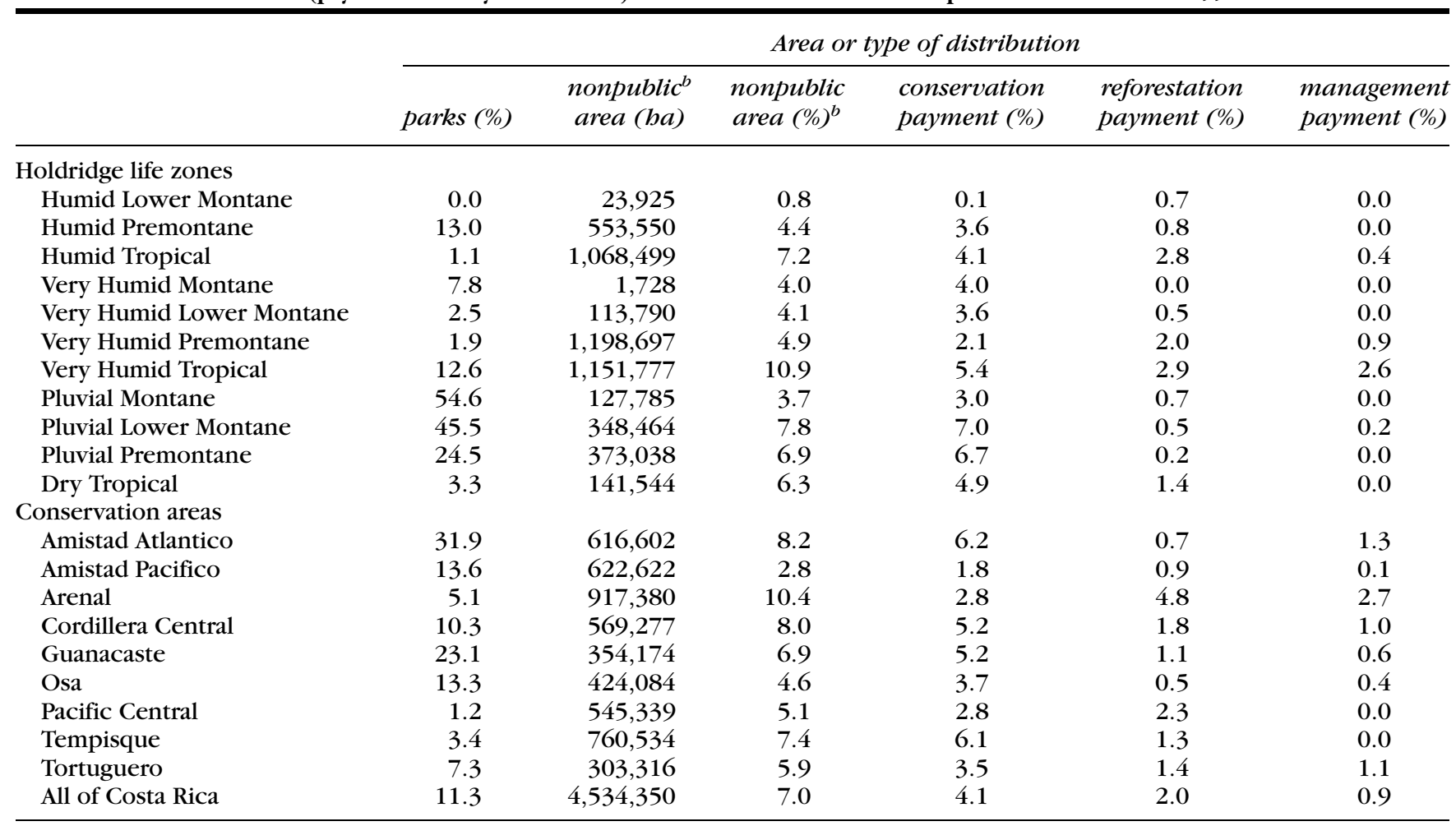

${ }^{a}$ Distribution is presented across Holdridge life zones and conservation areas.

${ }^{b}$ Areas outside national parks and biological reserves. 
Table 2. Distribution of PSA (payments for ecosystem services) in Costa Rica from 1997 to 2000 for areas outside national parks and biological reserves linked to conservation activities.

\begin{tabular}{|c|c|c|c|c|c|c|}
\hline \multirow[b]{2}{*}{ Conservation activity } & \multicolumn{6}{|c|}{ Area or type of distribution } \\
\hline & parks (\%) & $\begin{array}{c}\text { nonpublic }^{a} \\
\text { area }(\text { ba) }\end{array}$ & $\begin{array}{c}\text { nonpublic }^{a} \\
\text { area }(\%)\end{array}$ & $\begin{array}{l}\text { conservation } \\
\text { payment (\%) }\end{array}$ & $\begin{array}{l}\text { reforestation } \\
\text { payment (\%) }\end{array}$ & $\begin{array}{l}\text { management } \\
\text { payment (\%) }\end{array}$ \\
\hline \multicolumn{7}{|l|}{ Urban water quality } \\
\hline San Jose's \& three others ${ }^{b}$ & 6.7 & $1,102,459$ & 3.6 & 2.3 & 1.1 & 0.2 \\
\hline all other basins & 13.0 & $3,388,882$ & 8.1 & 4.7 & 2.3 & 1.1 \\
\hline \multicolumn{7}{|l|}{ Hydropower interests } \\
\hline actual \& planned dams ${ }^{c}$ & 13.4 & $1,597,442$ & 5.1 & 2.6 & 1.8 & 0.7 \\
\hline all other basins & 10.5 & $2,893,899$ & 8.1 & 4.9 & 2.1 & 1.0 \\
\hline \multicolumn{7}{|l|}{ Near current protected areas } \\
\hline $\operatorname{near}(<5 \mathrm{~km})$ & 0.0 & 793,630 & 7.0 & 5.2 & 1.2 & 0.6 \\
\hline $\operatorname{far}(>5 \mathrm{~km})$ & 0.0 & $3,620,916$ & 6.5 & 3.4 & 2.1 & 0.9 \\
\hline \multicolumn{7}{|l|}{ In planned protected areas } \\
\hline within GRUAS corridors & 0.0 & 631,934 & 9.9 & 6.1 & 2.2 & 1.7 \\
\hline outside GRUAS corridors & 0.0 & $3,787,737$ & 6.3 & 1.9 & 0.8 & 3.6 \\
\hline
\end{tabular}

${ }^{a}$ Nonpublic: areas outside national parks and biological reserves.

${ }^{b}$ Reventazon, Frio, Tarcoles, Terraba basins.

${ }^{c}$ Reventazon, Frio, Tarcoles, Terraba, Sixaola, Pacuare, San Carlos, Savegre basins.

Forest (10.9\%) and the lowest allocation was observed for the Humid Lower Montane (0.8\%). Of the three types of incentives that were part of the first phase of the PSA program, the conservation incentives dominated. Fewer incentives for conservation were present in the Humid Lower Montane life zone (0.1\%) and more incentives were in the Pluvial Lower Montane life zone (7\%).

There was a broad distribution of PSA contracts across the country's nine conservation areas. These units mostly had $4-8 \%$ of their total area under PSAs contracts, although Arenal (10.4\%) and Amistad Pacifico (2.8\%) differed from the other conservation areas. For these conservation units, the spatial allocation across the types of PSA contracts also varied.

Priorities for the allocation of PSA contracts as a function of hydrologic basins indicated two main trends (Table 2). First, from an urban quality point of view, PSA contracts were allocated more often in basins with little or no importance for drinking water $(13 \%$ for all other basins vs. $6.7 \%$ for San Jose's and three other important water-supply drainage basins). Second, actual and planned basins with dams received more investment than all other basins ( $13.4 \%$ vs. $10.0 \%$, respectively).

Our results (Table 2) also indicate that there was relatively little difference in the intensity of PSA contracts (number of parcels per unit area) relative to their proximity to conservation areas, and differed little among locations $(7.0 \%$ near $[<5 \mathrm{~km}]$ conservation areas vs. $6.5 \%$ farther from $[>5 \mathrm{~km}]$ conservation areas). Nevertheless, the differences in intensity for areas within and outside planned biological corridors were larger $(9.9 \%$ in the GRUAS plans and $6.3 \%$ outside of the GRUAS plans). For all cases (hydrologic basins, conservation locations, planned protected areas) conservation incentives dominated over the reforestation and management incentives.

\section{Impact of the PSA Program on Deforestation}

Costa Rica experienced very low deforestation rates during the study period. Deforestation rates were estimated to be $0.06 \% /$ year and $0.03 \%$ /year for the 1986-1997 and 1997-2000 time periods, respectively. Of the total distribution of PSA payments in the country, only $7.7 \%$ were located within $1.0 \mathrm{~km}$ of all deforestation fronts. Conservation payments were higher (3.6\%) than reforestation (2.6\%) and forest management (1.5\%) payments in areas close to deforestation fronts. A PSA payment was only slightly more likely to be near deforestation fronts $(1 \mathrm{~km})$ than to be farther away from them. Our results also indicate that there was no negative significant coefficient for the density of PSA payments (Table 3). The first generation of the PSA program did not reduce deforestation rates or total deforestation in Costa Rica (Table 3, Fig. 2).

\section{Discussion}

Costa Rica's PSA program has been a leader in the institutionalization of ecosystem investments through the now popular idea of payments for ecosystem services. We documented the spatial distribution of the first phrase of the PSA program (1997-2000) through GIS overlays with various indicators associated with conservation goals. The first phase of PSA contracts were distributed broadly along these dimensions and lacked sharp asymmetries that could indicate focused targeting. The sharpest asymmetry was for planned biological corridors. Furthermore, our econometric results suggest little, if any, impact of the level of PSA contracts on a given area's rate of deforestation. This has also been suggested by Hartshorn et al. (2005). 
Table 3. Results of regression analysis for Costa Rica's 1997-2000 deforestation, PSA (payments for ecosystem services) (conservation, reforestation, and management incentives [all] vs. conservation incentives alone), and selected control variables. ${ }^{a}$

\begin{tabular}{|c|c|c|c|c|c|c|}
\hline & all & $\begin{array}{c}\text { conservation } \\
\text { alone }\end{array}$ & all & $\begin{array}{c}\text { conservation } \\
\text { alone }\end{array}$ & all & $\begin{array}{c}\text { conservation } \\
\text { alone }\end{array}$ \\
\hline Payments & $\begin{array}{c}-0.0004 \\
(0.92)\end{array}$ & $\begin{array}{c}-0.004 \\
(0.48)\end{array}$ & $\begin{array}{c}0.001 \\
(0.83)\end{array}$ & $\begin{array}{c}-0.0005 \\
(0.92)\end{array}$ & $\begin{array}{c}-0.0003 \\
(0.95)\end{array}$ & $\begin{array}{r}-0.002 \\
(0.68)\end{array}$ \\
\hline Constant & $\begin{array}{c}0.004 \\
(0.00)\end{array}$ & $\begin{array}{c}0.004 \\
(0.00)\end{array}$ & $\begin{array}{c}0.016 \\
(0.00)\end{array}$ & $\begin{array}{c}0.016 \\
(0.00)\end{array}$ & $\begin{array}{c}0.011 \\
(0.01)\end{array}$ & $\begin{array}{c}0.011 \\
(0.01)\end{array}$ \\
\hline Good life zone $^{b}$ & & & $\begin{array}{c}-0.0002 \\
(0.93)\end{array}$ & $\begin{array}{c}-0.0002 \\
(0.94)\end{array}$ & $\begin{array}{l}0.0001 \\
(0.95)\end{array}$ & $\begin{array}{l}0.0001 \\
(0.94)\end{array}$ \\
\hline Poor life zone ${ }^{b}$ & & & $\begin{array}{c}-0.004 \\
(0.02)\end{array}$ & $\begin{array}{c}-0.004 \\
(0.02)\end{array}$ & $\begin{array}{c}-0.002 \\
(0.36)\end{array}$ & $\begin{array}{c}-0.002 \\
(0.37)\end{array}$ \\
\hline Distance to San Jose & & & $\begin{array}{r}-4 e 08 \\
\quad(0.41)\end{array}$ & $\begin{array}{r}-4 e 08 \\
\quad(0.40)\end{array}$ & $\begin{array}{l}4 e 09 \\
\quad(0.93)\end{array}$ & $\begin{array}{l}4 e 09 \\
\quad(0.93)\end{array}$ \\
\hline$\%$ cleared $^{c}$ & & & & & $\begin{array}{c}0.008 \\
(0.00)\end{array}$ & $\begin{array}{c}0.008 \\
(0.00)\end{array}$ \\
\hline Adjusted $R^{2}$ & 0.00 & 0.00 & 0.04 & 0.04 & 0.04 & 0.04 \\
\hline$n$ & 2021 & 2021 & 1892 & 1892 & 1887 & 1887 \\
\hline
\end{tabular}

${ }^{a}$ All regressions were ordinary least squares for deforestation probabilities. Coefficient is reported; $\mathrm{p}$ value in parentheses. The dependent variable was the deforestation rate during 1997-2000, measured at the level of the $5 \times 5 \mathrm{~km}$ grid units of observation. The explanatory variable of interest was the area receiving PSA payments, again measured by grid. We tried each of the two versions of the payments variable in each of the three sets of columns. Columns II and III added more control variables (i.e., explanatory variables other than PSA).

${ }^{b}$ See Methods for definition of good and poor life zones

${ }^{c}$ The fraction of the forest in a grid cell that was cleared before 1997.

From 1997 through 2000 little deforestation took place in Costa Rica (Figs. 2 \& 3). Yet some explanatory effects in the regressions were significant nonetheless (Table 3). Slope in particular was consistently and negatively associated with deforestation, whereas prior deforesta-

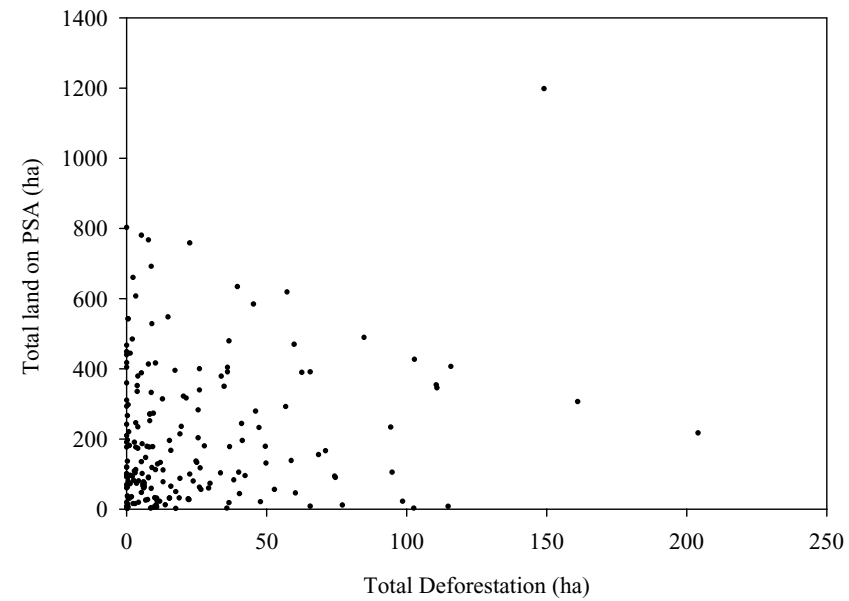

Figure 2. Relationship between the total area of farms in the PSA (payments for ecosystem services) program and the deforestation rate. The correlation coefficient between these two variables is 0.16 tion was consistently, positively, and significantly associated with deforestation. Distance to Limon was also significantly associated with deforestation. These results confirm many prior results in the literature (Velkamp et al. 1992; Sánchez-Azofeifa et al. 2002b; Van Laake

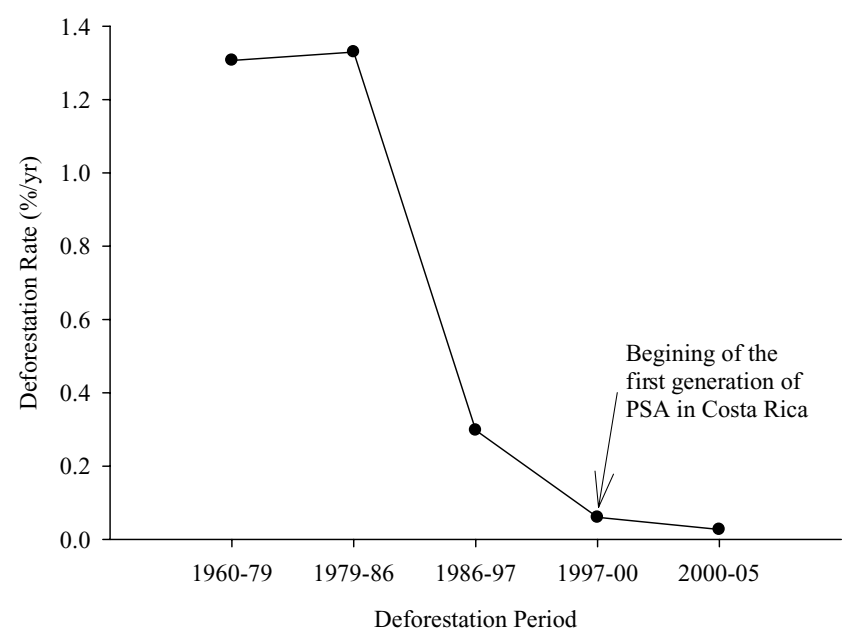

Figure 3. Changes in deforestation rates between 1960 and 2005. Arrow is implementation of the first PSA (payment for ecosystem services) program. 
\& Sánchez-Azofeifa 2004; Schelhas \& Sánchez-Azofeifa 2006, among others). With or without controlling for these other deforestation-driving variables, the level of PSA contracts in an area never generated significant statistical results concerning a reduction in the country's deforestation rate.

We believe the results from our regression analysis reflect the significant impact of previous forest conservation policies in Costa Rica, including a 1997 legal restriction on forest clearing (Law 7575, De Camino et al. 2000; Hartshorn et al. 2005). All of the prior policies, including the creation of national parks and biological reserves and the 1997 law, have very effectively lowered deforestation. Nevertheless, the roles of other changes, such as in market prices, need to be considered when interpreting our results. The success of these previous programs subsequently left the PSA program with little forest clearing to prevent, thereby constraining the maximum possible impact of PSA payments, which turned out to be relatively low as a result.

In the Costa Rican case PSA contracts may not have targeted deforestation pressure explicitly because this was not the original purpose of the program. In fact, the PSA contracts may have been targeted where there was a lack of deforestation pressure because the level of PSA contracts correlated negatively with the 1986-1997 forest clearing. This could have resulted from a policy design in which the PSA contracts were fixed across space (i.e., each of the locations in the country is assumed to provide the same services and is offered the same level of payment per hectare) and enrollment was voluntary. Targeting of these kinds of lands could lead to those with unprofitable or low-profit land being the dominant participants in the program.

The nonrandom location of the first phase of PSA contracts is important to consider as well (Wilson et al. 2006). Given considerable agency expertise in Costa Rica, and good local data, the PSA program could have targeted threatened species so the impact could be greater than it initially appeared to be. Yet because land owners chose whether or not to participate, lower profitability lands could dominate the program and a large fraction of payments could go to those who would have kept their lands in forest regardless of payments due to low opportunity costs (Newburn et al. 2005; Sierra \& Russman 2006).

This self-selection for the PSA program could satisfy various policy goals, but it would not influence the country's deforestation rate. Future work should examine more closely the extent to which such self-selection has influenced the location of PSA contracts. Despite the fact that Costa Rica's effective conservation history is somewhat unique and that in many countries deforestation may be higher, this policy design consideration is an important point that is relevant elsewhere. It is also consistent with work on policy location in Mexico (Muñoz-Piña et al. 2005) and some prior work in Costa Rica (Sierra \& Russman 2006).

Future work could also examine the effect of increased ecological targeting in the PSA program over time (e.g., post-2000). Perhaps future research could investigate whether the expected benefits from the PSA contracts would rise even if impacts on the country's deforestation rates did not. Another important question to research is how impacts on deforestation could be increased. Further targeting of deforestation threats in subsequent studies may help, but may require spatial variation in policies. For example, research should address targeting and variations in payment levels (Wilson et al. 2006).

We believe Costa Rica's pioneering effort opens the door to further successful PSA programs. The evaluation of its first phase provides important conservation lessons for developing countries interested in similar policies (Newburn et al. 2005) and for new global policies.

\section{Acknowledgments}

A Standard Research Grant from the Social Science and Humanities Research Council of Canada (SSHRC) to A.S.A funded this work. We thank the support and collaboration of the Costa Rica National Forest Financing Fund (FONAFIFO). We thank three anonymous reviewers for constructive and positive review comments and E. Main, who helped improve this manuscript. We also thank R. Chazdon, P. Ferraro, C. Leon, M. Guariguata, C. Orosz, M. Kalacska, and C. M. Rodríguez for constructive and positive comments.

\section{Literature Cited}

Arroyo-Mora, J. P., G. A. Sánchez-Azofeifa, B. Rivard, J. C. Calvo, and D. H. Janzen. 2005. Dynamics in landscape structure and composition for the Chorotega region, Costa Rica from 1960 to 2000. Agriculture, Ecosystems and Environment 106:27-39.

Camacho, A., and V. Reyes. 2002. Pago por servicios ambientales. Octavo informe sobre el estado de La Nacion en desarrollo humano sostenible. Consejo Nacional de Rectores, San José, Costa Rica.

Castro, R., F. Tattenbach, L. Gámez, and N. Olson. 1998. The Costa Rican experience with market instruments to mitigate climate change and conserve biodiversity. Fundacion para el Desarrollo de la Coordillera Volcanica Central (FUNDECOR), San José, Costa Rica.

De Camino, R., O. Segura, L. G. Arias, and I. Perez. 2000. Costa Rica: forest strategy and the evolution of land use. The World Bank, Washington, D.C.

Ferraro, P. 2001. Global habitat protection: limitations of development interventions and a role for conservation performance payments. Conservation Biology 15:990-1000.

Ferraro, P., and A. Kiss. 2002. Direct payments to conserve biodiversity. Science 298: 1718-1719.

Hartshorn, G., P. Ferraro, B. Spergel, and E. Sills. 2005. Evaluation of the World Bank-GEF Ecomarkets project in Costa Rica. North Carolina State University, Durham.

Holdrighe, L. 1967. Life zone ecology. Tropical Science Center, San José, Costa Rica. 
Janzen, D. H. 1998. Gardenification of wildland nature and the human footprint. Science 279:1312-1313.

Miranda, M., I. Porras, and M. L. Montero. 2003. The social impacts of payments for environmental services in Costa Rica: a quantitative field survey and analysis of the Virilla watershed. Environmental Economics Programme, London.

McNeely, J. A., and S. J. Scherr. 2002. Ecoagriculture: strategies to feed the world and save wild biodiversity. Island Press, Washington, D.C.

Newburn, S. Reed, P. Berck, and A. Merenlender. 2005. Economics and land use change in prioritizing land conservation. Conservation Biology 19:1411-1420.

Muñoz-Piña, C., A. Guevara, J. M. Torres, and J. Braña. 2005. Paying for environmental services of Mexico's forests: analysis, negotiations and results. Instituto Nacional de Ecologia, Universidad Nacional Autonoma de Mexico, Mexico, D.F.

Ortiz, E., and J. Kellenberg. 2002. Program of payments for ecological services in Costa Rica. World Conservation Union, Washington, D.C.

Pagiola, S., J. Bishop, and N. Landell-Mills, editors. 2002. Selling forest environmental services: market-based mechanisms for conservation and development. Earthscan Publications, London.

Pagiola, S., K. von Ritter, and J. Bishop. 2004. Assessing the economic value of ecosystem conservation. Environment department papers, paper 101. The World Bank, Washington, D.C

Pfaff, A., and G. A. Sánchez-Azofeifa. 2004. Deforestation pressure and biological reserve planning: a conceptual approach and an illustrative application for Costa Rica. Resource and Energy Economics 26:237254.

Sánchez-Azofeifa, G. A., R. C. Harriss, and D. Skole. 2001. Deforestation in Costa Rica: a quantitative analysis using remote sensing imagery. Biotropica 33:378-384.
Sánchez-Azofeifa, G. A., R. C. Harriss, L. Storrier, and T. De-CaminoBeck. 2002a. Water resources and regional land cover change in Costa Rica: impacts and economics. International Journal of Water Resources Development 18:109-424.

Sánchez-Azofeifa, G. A., B. Rivard, J. C. Calvo, and I. Moorthy. $2002 b$. Dynamics of tropical deforestation around national parks: remote sensing of forest change on the Osa Peninsula of Costa Rica. Mountain Research and Development 22:352-358.

Sánchez-Azofeifa, G. A., G. Daily, A. Pfaff, and C. Busch. 2003. Integrity and isolation of Costa Rica's national parks and biological reserves: examining the dynamics of land cover change. Biological Conservation 109:123-135.

Schelhas, J., and G. A. Sánchez-Azofeifa. 2006. Post-frontier forest change adjacent to Braulio Carrillo National Park, Costa Rica. Human Ecology 34:407-431.

Sierra, R., and E. Russman. 2006. On the efficiency of environmental services payments: a forest conservation assessment in the Osa Peninsula, Costa Rica. Ecological Economics 59:131-141.

Skole, D. L., and C. Tucker. 1993. Tropical deforestation and habitat fragmentation in the Amazon: satellite data from 1978 to 1988. Science 260:1905-1910.

Van Laake, P., and G. A. Sánchez-Azofeifa. 2004. Focus on deforestation. Agriculture, Ecosystems and Environment 102:3-15.

Velkamp, E., A. M. Weitz, Starisky, and I.G. Huising. 1992. Deforestation trends in the Atlantic Zone of Costa Rica: a case study. Land Degradation and Rehabilitation 3:71-84.

Wilson K. A., M. F. McBride, M. Bodel, and H. P. Possingham. 2006. Prioritizing global conservation efforts. Nature 440:337-340.

Zbinden S., and D.R. Lee. 2005. Paying for environmental services: an analysis of participation in Costa Rica's PSA program. World Development 33:255-272. 